\title{
Firm Performance and Entrepreneurial, Market and Technology Orientations in Korean Technology Intensive SMEs
}

\author{
Lee Do Hyung $^{1} \&$ Alisher Dedahanov ${ }^{2}$ \\ ${ }^{1}$ School of General Education, Yeungnam University, 280 Daehak-Ro, Gyeongsan, Gyeongbuk, 712-749, \\ Republic of Korea \\ ${ }^{2}$ Business School, Yeungnam University, 280 Daehak-Ro, Gyeongsan, Gyeongbuk, 712-749, Republic of Korea \\ Correspondence: Alisher Dedahanov, Business School, Yeungnam University, 280 Daehak-Ro, Gyeongsan, \\ Gyeongbuk, 712-749, Republic of Korea. E-mail: sarbon22513@gmail.com
}

Received: September 1, 2013 Accepted: April 23, 2014 Online Published: October 30, 2014

doi:10.5539/ass.v10n22p37 URL: http://dx.doi.org/10.5539/ass.v10n22p37

\begin{abstract}
This study investigated the relationships between entrepreneurial-market orientations and entrepreneurial-technology orientations and the impact of market and technology orientations on firm performance in Korean technology intensive small and medium-sized business (SMEs). To conduct the analysis, the study applies structural equation modeling (SEM) to understand the direct effects of entrepreneurial on market and technology orientations and the direct effects of market and technology orientations on firm performance. This research is based on a study of 347 technologies intensive Korean SMEs and the major results are as follows:

The results indicate that entrepreneurial orientation directly affects market and technology orientations. This result implies that entrepreneurial orientation is key factors that influence market and technology orientation in Korean SMEs. Another finding suggests that market and technology orientations positively affect firm performance. It appears that Korean companies require the capability to serve technology well, but also need to recognize new business opportunities from within their current market relationships. The implication here is that for Korean technology intensive small firms, entrepreneurial orientation can improve market and technology orientations. The results suggest that to achieve high levels of firm performance, Korean companies need to balance the elements of entrepreneurial, technology and market orientations.
\end{abstract}

Keywords: entrepreneurial orientation, market orientation, technology orientation, firm performance, Korean SMEs

\section{Introduction}

A large body of academic literature has been published on the subject of strategic orientation. Research focusing on investigating a single orientation has led to a lack of more complex and multi-dimensional approaches to strategic orientation that adopt a holistic perspective (Hakala, 2010). This narrow focus has in turn led to gaps in the literature regarding how to combine various orientations and the likely effects on firm performance.

Therefore, the significance of examining the relationships among different strategic orientations has increased (Grinstein, 2008). Recent studies have suggested that research should focus on the various combinations of strategic orientations that organizations can pursue in different environments, rather than on direct effect between a single orientation and firm performance (Grinstein, 2008).

However, little research based on empirical data studying the combined use of market, technology and entrepreneurial orientations in conjunction with one another exists (Aloulou \& Fayolle, 2005; Hakala, 2010; Kaya \& Seyrek, 2005), and only a small number of studies have attempted to examine the link-between technology, market and entrepreneurial orientations (Aloulou and Fayolle, 2005; Kaya and Seyrek, 2005; Li, 2005; Zhou, Yim, \& Tse, 2005). Aloulou and Fayolle (2005) explored the main attributes of entrepreneurial orientation and its determinants from opportunity-based and resource-based views within a small business context. However, this study was somewhat limited because of its purely conceptual nature. These works present orientations on a conceptual level only (Aloulou \& Fayolle, 2005), and other studies investigate the effects of these orientations separately (Li, 2005; Zhou et al., 2005) rather than viewing the effects of combined 
orientations.

Kaya and Seyrek (2005) investigated the various effects of entrepreneurial, technology and customer orientations on firm performance with different levels of market dynamism. Their findings suggest a strong positive relationship between entrepreneurial orientation and firm performance for firms in highly dynamic markets and a positive link between technology orientation and firm performance in less dynamic markets. This study focused on the effects of orientations under different market conditions rather than identifying the relationship between each orientation. The study by Zhou et al. (2005) conceptualized a model that connects strategic orientations (market, technology and entrepreneurial orientations) and market forces through organizational learning that leads to breakthrough innovations and firm performance. In this study, technology orientation has a positive impact on tech-based innovations and entrepreneurial orientation is positively associated with both market- and tech-base innovations. However, this study focuses on the distinct effects of different orientations and, therefore, fails to study the combined effects of multiple orientations.

Thus, we attempt to contribute to the current knowledge by filling the following research gaps. First, many studies focus on a specific orientation or on the direct effects of each respective orientation, neglecting to consider the potential they have to function as a system. Second, most of empirical examinations were undertaken in the context of advanced economies and large firms.

In this vein, the purpose of this paper is twofold. First, we investigate the relationship between entrepreneurial-market orientation and entrepreneurial-technology orientation. Second, we examine the direct effects of the entrepreneurial orientation on market and technology orientations in the context of SMEs. Next, we suggest possible implications to raise firm performance in the context of emerging country SMEs.

\section{Literature Review and Hypotheses}

\subsection{The Relationship between Entrepreneurial and Technology Orientations}

Entrepreneurial orientation has long been recognized as the key for initiating innovative activities (Miller, 1983). The view purported by Miller (1983) that the level of entrepreneurial orientation adopted by a firm is dependent on the level of pro-activeness, innovativeness and risk-taking, is widely supported within the existing academic literature (Madsen, 2007; Zahra \& Covin, 1995). Entrepreneurial orientation is closely related to a proactive managerial mindset, a tendency to enter risky markets, and a propensity to act boldly and extensively to achieve a goal (Miller, 1987; Covin \& Slevin, 1989).

Technology orientation refers to a firm's inclination to introduce or use new technologies and products (Gatignon \& Xuereb, 1997; Hult, Hurley, \& Knight, 2004). Hubert and Xuereb (1997, p. 78) define technology orientation as having "... the ability and will to acquire substantial technological background and use it in the development of new products. Technology orientation also means that the company can use its technical knowledge to build a new technical solution to answer and meet new needs of the users."

Whereas various authors suggest that technologically oriented firms are required to behave in an entrepreneurial manner to present their innovations as commercial products, a number of factor suggest that entrepreneurial orientation affects the level of technology orientation. The pro-activeness often associated with entrepreneurial orientation may mean that organizations adopting this strategic orientation will invest in new technologies to gain first-mover advantages. Previous research (Miller, 1983) examining pro-activeness and strategic orientation has also found that entrepreneurs who exhibit high levels of pro-activeness and risk-taking often create a greater number of unique products. This finding is indicative of technology orientation. The innovativeness often associated with entrepreneurial orientation helps to develop new technologies, while risk-taking through entrepreneurial behavior facilitates investment in products and technologies in which a return is uncertain (Miller \& Friesen, 1982; Wiklund \& Shepherd, 2005).

Previous research demonstrated that a positive relationship indicates that entrepreneurial orientation has a direct effect on technology orientation (Hakala, 2011; Wiklund \& Shepherd, 2005). This relationship gives entrepreneurial orientation an opportunity to affect technology orientation in a positive way. In short, entrepreneurial orientation is believed to have a strong relationship with technology orientation.

Based on the above discussion, the hypothesis is given as follows:

H1 Entrepreneurial orientation is positively related to technology orientation

\subsection{The Relationship between Entrepreneurial and Market Orientations}

Market orientation has thus far been conceptualized as either organizational behavior (Jaworski \& Kohli, 1993; Kohli \& Jaworski, 1990) or organizational culture (Deshpande, Farley, \& Webster, 1993; Homburg \& Pflesser, 
2000; Narver \& Slater, 1990). For instance, Narver and Slater (1990, p. 21) defined market orientation as "the organization culture that most effectively and efficiently creates the necessary behaviors for the creation of superior value for buyers and, thus, continuous superior performance for the business." These researches have stated that market orientation consists of the following three behavioral components: customer orientation, competitor orientation, and inter-functional coordination. Kohli and Jaworski (1990) have defined market orientation as composed of the following three sets of activities: the organization-wide generation of market intelligence; the dissemination of that intelligence across departments; and organization-wide responsiveness to that information. Although numerous other studies concerning market orientation have been conducted, the majority of authors have either adopted the definition of Kohli and Jaworski (1990) or that of Narver and Slater (1990). Our study adopts Narver and Slater's (1990) definition because of its focus on the aspect of a culture that creates values.

Entrepreneurial orientation refers to the processes, practices and decision-making activities employed by entrepreneurs that lead to new entry (Lumpkin \& Dess, 1996, p. 136).

Entrepreneurial and market orientations are strategic tools to face an unstable and dynamic market trend itself. If only market orientation is the focus, one can have a limited strategic perspective on the current business area. Conversely, organizations that concentrate only on entrepreneurial orientation may obtain a high income through innovation.

Entrepreneurial firms often develop new business by using their current resource base; entrepreneurial orientation, thus, can lead to an increase in market orientation (Hakala, 2010). Therefore, market orientation that is based on entrepreneurial orientation can perceive the importance of the market (Kohli \& Jaworski, 1990; Slater \& Narver, 1995). Entrepreneurial orientation may point toward efforts to better understand customers (Atuahene-Gima \& Ko, 2001; Bhuian, Menguc, \& Bell, 2005; Li, Liu, \& Zhao, 2008).

The more that an entrepreneurial orientation is encouraged; the more information businesses tend to gain regarding customer needs and competitor information (Barringer \& Bluedorn, 1999). Moreover, there firms have an organizational culture that allows employees to share and use basic information regarding market orientation (Menon \& Varadara-jan, 1992). In other word, entrepreneurial orientation is an antecedent of market orientation.

Previous research suggests that entrepreneurial orientation has a direct effect on market orientation (Baker \& Sinkula, 2009; Hakala, 2011). Baker and Sinkula (2009) indicated that entrepreneurial orientation enhances market orientation by encouraging a culture that promotes firm performance.

Based on the above discussion, the hypothesis is given as follows:

H2 Entrepreneurial orientation is positively related to market orientation

\subsection{The Relationship between Technology Orientation and Firm Performance}

Technology orientation is purported by numerous authors to positively contribute to firm performance (Gao, Zheng, \& Yim, 2007; Gatignon \& Xuereb, 1997). This orientation is often considered an important source of organizational growth and innovation in many industries that feature an increased use of innovative technology (Zhou \& Li, 2010). Roger (1983) argues that technology orientation assists organizations in adopting and utilizing new ideas and technologies earlier than their competitors. Technology-oriented firms invest heavily in $R \& D$ and accept state-of-the-art technology. With the technological knowledge in the organization, technology-oriented firms tend to be innovative in management.

Previous research suggests that technology orientation has a direct effect on firm performance (Gao et al., 2007; Gatignon \& Xuereb, 1997; Zhou \& Li, 2010). Hamel and Prahalad (1994) indicate a close relationship between technology orientation and firm performance. Zhou and Li (2010) suggest that technology orientation has a stronger effect on firm performance when market demand becomes increasingly uncertain.

It is perceived that technology orientation may be the key impetus for firm performance. In this vein, previous studies found that technology orientation positively influences firm performance (Hamel \& Prahalad, 1994). These ideas and empirical findings point to the role of technology orientation as a potential antecedent of firm performance. Based on the above discussion, the hypothesis is given as follows:

H3 Technology orientation is positively related to firm performance.

\subsection{The Relationship between Market Orientation and Firm Performance}

The positive link between market orientation and firm performance has been widely highlighted (Ramaseshan, Caruana, \& Pang, 2002; Farrell, Oczkowski, \& Kharabsheh, 2008). Haugland, Myrtveit and Nygaard (2007) indicated the effect of market orientation on firm performance. This research conducted that market orientation 
appeared to have a strong effect on firm performance. In addition, Martin-Consuegra and Esteban (2007) confirmed that market orientation is a key element of firm performance in the airline sector.

Similarly, the positive association between market orientation and firm performance has been proven in context of SMEs. Liu and Davies (1997) explained that market orientation is linked to higher firm performance in UK SMEs. In addition, Megicks and Warnaby (2008) found that market orientation is positively linked to firm performance. Ramaseshan et al. (2002) examined the relationship between market orientation and new product performance in Singaporean firms. The findings underpinned the proposition that market orientation positively contributes to the overall performance of new products. These researchers noted that enhancing market orientation is important because this orientation involves more regular research on current and changing customers' expectations and the collected ideas should be reflected in the new product development stage, thereby reinforcing the ability to offer new products to satisfy customers' needs and to achieve better firm performance.

Based on the above discussion, the hypothesis is given as follows:

H4 Market orientation is positively related to firm performance.

\section{Method}

\subsection{Sample and Data Collection}

We tested this model using a questionnaire survey of technology-intensive SMEs in the Dae-Gu/Gyeong-Buk area of South Korea. The sample was drawn from the South Korean Small and Medium Business Administration (SMBA) and checked against a list provided by the Korean Inno-biz Association. Inno-biz firms are certified by the Korean government as technology-intensive and innovation-oriented SMEs that produce technologically advanced products. The Dae-Gu/Gyeong-Buk region has emerged as an important hub for high-tech science and $R \& D$ and is therefore ideal for our research. The region has an established a R\&D infrastructure, cooperation between industry and academia, and a number of public research institutes and technology research centers supporting companies' R\&D activities. To increase response rates, we made personal, face-to-face contact with CEOs or senior managers of the firms to whom we sent questionnaires. Having contacted 1000 firms, a total of 347 usable questionnaires were used, yielding a response rate of $34.7 \%$. The characteristics of the sample are shown in Table1.

Table 1. Characteristics of the sample $(\mathrm{N}=347)$

\begin{tabular}{lll}
\hline Variable & Frequency & Percentage \\
\hline Type of Business & & \\
Electricity/Electronics & 60 & 17.3 \\
Machine/Machine parts & 131 & 37.8 \\
Automobile/Car parts & 102 & 39.4 \\
Primary metal/Metal working & 54 & 15.6 \\
Year of Establishment & & \\
1990 ago & 92 & 26.5 \\
1991-2000 & 150 & 43.2 \\
Over 2001 & 105 & 30.3 \\
Number of Employees & & \\
Under 10 & 46 & 13.3 \\
$11-20$ & 93 & 26.8 \\
$21-50$ & 122 & 35.2 \\
$51-100$ & 54 & 15.6 \\
Over 101 & 32 & 9.2 \\
\hline
\end{tabular}

\subsection{Scale Construction}

The operationalization of constructs on the questionnaire was made using 5-point Likert scales, ranging from 1 (strongly disagree) to 5 (strongly agree). The items used for each scale are shown in Table 3 along with their standardized loadings. We used summed scales. Although this approach has been criticized by certain authors 
(Oczkowski \& Farrell, 1998), it is a technique that has often been used in previous related research (Hult et al., 2004; Brown \& Peterson, 1994; Hartline \& Ferrell, 1996).

Entrepreneurial orientation (EO) Researchers agree that entrepreneurial orientation is a concept that is comprised of risk taking, innovativeness, and pro-activeness (Miller, 1983; Covin \& Slevin, 1990; Zahra \& Covin, 1995). Based on the research of Miller (1983), Lumpkin and Dess (1996) and Frishammar and Hörte (2007), we captured entrepreneurial orientation as the willingness to accept risk-taking and to engage in pro-activeness and innovativeness.

Market orientation (MO) We built a scale for market orientation based on the constructs of customer orientation, competitor orientation, and inter-functional coordination to satisfy customer needs (Narver \& Slater, 1990). We used the established scale developed by Narver and Slater (1990) that captures these components and emphasizes the consideration of stakeholders when reacting to market information.

Technology orientation (TO) We built a scale for technology orientation following the concept developed in Gatignon and Xuereb's (1997) study. This scale captures the propensity of the firm to consider the latest technology, invest in the use of advanced technologies in new product development, emphasize technological forecasting, and recruit well-trained R\&D personnel.

Firm performance (FP) Following Akgun et al. (2007), we asked respondents to provide data on the performance of their company relative to major competitors over the previous three years. We used the following four aspects of performance: market share, growth rate, and so on (Akgun et al., 2007).

Control variable Firm size was assessed via the number of full-time employees of their firms (Gulati and Higgins, 2003). Murphy et al. (1996) argued that the turnover has a significant impact on measuring the firm size by comparing from previous year and this study has used firm size as control variable.

\subsection{Data Analysis and Quality}

To ensure the reliability and validity of the data we conducted following tests.

We applied key parameters method to examine sample selection bias (Park \& Ghauri, 2011). In our study key parameters are firm age and firm sales. By conducting a t-test, we did not find significant differences between the total target population and the means of the used sample. We also distinguished the non-sample and sample firms. Results revealed that two samples are statistically similar (firm age: $p=0.472$, firm sales: $p=0.723$ ). These results indicate that sample selection bias is not likely to be a problem in this study.

Second, we utilized several methods to analyze common method variance. To avoid this problem, measurement items on the questionnaire were structured in random and non-sequential order to mitigate consistency bias. In order to overcome social desirability bias assured participants' confidentiality (Podsakoff et al., 2003, p. 888). Questionnaire including dependent variable items were collected 10 weeks after receiving the questionnaires that include independent variables. Finally, we conducted Harman's single-factor test (Podskaoff et al., 2003). We utilized a confirmatory factors analysis by including all items and examined whether a single factor emerged. Results demonstrate very poor model fit for a single factor $(\chi 2=1365.587(\mathrm{df}=152, \mathrm{p}=0.000), \chi 2 / \mathrm{df}=8.984$, $\mathrm{GFI}=0.682, \mathrm{AGFI}=0.603, \mathrm{RMR}=0.059, \mathrm{RMSEA}=0.137, \mathrm{NFI}=0.769, \mathrm{TLI}=0.762, \mathrm{CFI}=0.788)$.

Although we cannot eliminate the potential for common method variance, these measures mean that variance is unlikely to account for any observed relationship among the variables of interest.

Third, we checked for multicollinearity issue among variables by testing variance inflation factor (VIF) values. Multicollinearity issue is likely to be a major concern when variation inflation factors (VIF) $>10$ and tolerance values are < 0.1 (Hair et al., 2006). VIF values ranged between 1.826 and 2.892 and the lowest tolerance was 0.346. Therefore, multicollinearity issue is not considered to be a major concern of this study.

\section{Results}

Table 3 presents the means, standard deviations, and correlation coefficients of all the variables. Using the Pearson correlation $r$, which estimates the degree of linear association, a correlation analyses was conducted. -1.00 to +1.00 is the range for correlation value (Kline, 2005). Table 3 outlines the correlations of all 5 constructs. This analysis shows that there was a moderate correlation between these four constructs. The results show that there was high correlation among entrepreneurial orientation, technology orientation, market orientation, and firm performance. 
Table 2. Final measurement model

\begin{tabular}{|c|c|}
\hline Scale & $\begin{array}{l}\text { Standardized } \\
\text { loadings }\end{array}$ \\
\hline \multicolumn{2}{|l|}{ Market orientation $(\mathrm{MO})(\alpha=.928)$} \\
\hline \multicolumn{2}{|l|}{ Competitor orientation } \\
\hline We rapidly respond to competitive actions that threaten us. & 0.72 \\
\hline Our salespeople regularly share information concerning competitors'strategies. & 0.83 \\
\hline Top management regularly discusses competitors' strengths and strategies. & 0.73 \\
\hline \multicolumn{2}{|l|}{ Inter-functional coordination } \\
\hline Our business objectives are driven primarily by customer satisfaction. & 0.81 \\
\hline Our strategy for competitive advantage is based on our understanding of customer needs. & 0.82 \\
\hline Our strategies are driven by beliefs about how we can create greater value for customers. & 0.85 \\
\hline We measure customer satisfaction systematically and frequently. & 0.75 \\
\hline \multicolumn{2}{|l|}{ Customer orientation } \\
\hline All of our business functions are integrated in serving the needs of our target markets. & 0.70 \\
\hline All of our business functions are responsive to each other's needs and requests. & 0.81 \\
\hline $\begin{array}{l}\text { Our top managers from every function regularly visit our current and prospective } \\
\text { customers }\end{array}$ & 0.85 \\
\hline We communicate information about customer experiences across all business functions & 0.78 \\
\hline Our managers understand how we can contribute to creating customer value & 0.84 \\
\hline \multicolumn{2}{|l|}{ Technology orientation $(\mathrm{TO})(\alpha=.846)$} \\
\hline $\begin{array}{l}\text { The policy of this firm has been to always consider the most up to-date production } \\
\text { technology available. }\end{array}$ & 0.71 \\
\hline We spend more than most firms in our industry on new product development. & 0.72 \\
\hline We devote extra resources to technological forecasting. & 0.76 \\
\hline $\begin{array}{l}\text { We are actively engaged in a campaign to recruit the best qualified R\&D personnel } \\
\text { available. }\end{array}$ & 0.84 \\
\hline \multicolumn{2}{|l|}{ Entrepreneurial orientation (EO) $(\alpha=.898)$ Innovativeness } \\
\hline Technical innovation, based on research results, is readily accepted & 0.76 \\
\hline We actively seek innovative product and service ideas & 0.83 \\
\hline Innovation is readily accepted in program/project management in our company & 0.89 \\
\hline Innovation in our organization is encouraged. & 0.79 \\
\hline \multicolumn{2}{|l|}{ Risk-taking } \\
\hline We initiate actions to which other organizations respond. & 0.75 \\
\hline We are fast to introduce new products and services to the marketplace. & 0.96 \\
\hline \multicolumn{2}{|l|}{ Proactiveness } \\
\hline We have a strong proclivity for high-risk projects. & 0.75 \\
\hline \multicolumn{2}{|l|}{ Firm performance $(\mathrm{FP})(\alpha=.899)$} \\
\hline $\begin{array}{l}\text { In comparison with your major competitors over the past three years, our performance has } \\
\text { been more successful. }\end{array}$ & 0.81 \\
\hline $\begin{array}{l}\text { In comparison with your major competitors over the past three years, your company has } \\
\text { more market share. }\end{array}$ & 0.84 \\
\hline $\begin{array}{l}\text { In comparison with your major competitors over the past three years, your company has } \\
\text { more growth rate. }\end{array}$ & 0.89 \\
\hline $\begin{array}{l}\text { In comparison with your major competitors over the past three years, your company has } \\
\text { more profitability. }\end{array}$ & 0.87 \\
\hline Goodness-of-fit statistics & \\
\hline $\begin{array}{l}(\chi 2(71)=194.118, \mathrm{RMR}=0.026, \mathrm{GFI}=0.939, \mathrm{RMSEA}=0.064, \mathrm{NFI}=0.950, \mathrm{IFI}=0.968, \\
\mathrm{TLI}=0.959, \mathrm{CFI}=0.968)\end{array}$ & \\
\hline
\end{tabular}


Table 3. Scale means, standard deviations and correlations

\begin{tabular}{llllllll}
\hline Scale & Mean & S.D & 1 & 2 & 3 & 4 & 5 \\
\hline 1. EO & 3.90 & .64 & 1 & & & & \\
2. MO & 3.92 & .67 & $.664^{* *}$ & 1 & & & \\
3.TO & 4.03 & .66 & $.764^{* *}$ & $.595^{* *}$ & 1 & & \\
4. FP & 3.77 & .74 & $.495^{* *}$ & $.487^{* *}$ & $.448^{* *}$ & 1 & \\
5. Firm Size & 1.42 & .40 & -.089 & -.099 & -.173 & .036 & 1 \\
\hline
\end{tabular}

** significant at the .01 level (two-tailed); firm size was log transformed

Table 4 reports the results of the structural equation model. While the value of $x 2(83)=228.414, x 2 / \mathrm{df}=2.752$ is significant, the various other values in the measurement model indicate an adequate model fit $(\mathrm{RMR}=0.032$, GFI $=0.934, \mathrm{RMSEA}=0.064, \mathrm{NFI}=0.927, \mathrm{IFI}=0.962, \mathrm{TLI}=0.952, \mathrm{CFI}=0.962)$. The root mean residual $(\mathrm{RMR})$ falls within an acceptable range (less than 0.07) (Bagozzi \& Yi, 1988). The RMSEA considers the error of approximation in the population and is sensitive to the number of estimated parameters in the model. Values between 0.05 and 0.08, as we found in our constructs, are acceptable (Browne \& Cudeck, 1992).

Table 4. Results for the structural model

\begin{tabular}{llll}
\hline Path & Standardized coefficient & T-value & Hypothesis \\
\hline Entrepreneurial orientation $\rightarrow$ Market orientation (H1) & $0.782^{*}$ & 14.396 & Support \\
Entrepreneurial orientation $\rightarrow$ Technology orientation & $0.928^{*}$ & 17.038 & Support \\
(H2) & $0.328^{*}$ & 4.331 & Support \\
Market orientation $\rightarrow$ Firm performance $(\mathrm{H} 3)$ & $0.367^{*}$ & 4.809 & Support \\
Technology orientation $\rightarrow$ Firm performance $(\mathrm{H} 4)$ & 0.079 & 1.907 & \\
Farm size $\rightarrow$ Firm performance & & & \\
X2(83)=228.414, x2/df=2.752, RMR=0.032, GFI $=0.934$, RMSEA $=0.064, \mathrm{NFI}=0.927, \mathrm{IFI}=0.962, \mathrm{TLI}=0.952$, \\
$\mathrm{CFI}=0.962$ \\
$* \mathrm{p}<0.001$
\end{tabular}

The structural path coefficients allow us to determine whether we can reject our null hypotheses.

As Table 4 demonstrates, entrepreneurial orientation has a positive effect on market orientation $(\beta=.782, p<.001)$ as does technology orientation $(\beta=.928, p<.001)$. These results concur with various previous studies (Baker \& Sinkula, 2009; Hakala, 2011; Wiklund \& Shepherd, 2005). Thus, H1 and H2 were supported. Market orientation $(\beta=.328, p<.001)$ and technology orientation $(\beta=.367, p<.001)$ had a considerable effect on firm performance, which proved to be consistent with previous studies (Gao et al., 2007; Gatignon \& Xuereb, 1997; Zhou \& Li, 2010). These results indicate that both market orientation and technology orientation are crucial factors for encouraging firm performance. That is, the greater market and technology orientation of a firm, the more firm performance is emphasized and fostered within the organization. Thus, $\mathrm{H} 3$ and $\mathrm{H} 4$ were both supported.

\section{Discussion}

This study investigated the relationships between entrepreneurial-market orientations and entrepreneurial-technology orientations and the impact of market and technology orientations on firm performance in Korean SMEs. We comprehensively derived possible conceptual models and test them using a survey of emerging country SMEs. The main implications of our empirical findings are as follows.

First, this research goes towards highlighting the importance of developing a more integrated approach to studying the relationshipentrepreneurial orientation, market orientation, technology orientation and firm performance through a new model. The present study provided a more systematic explanation on how strategic orientation brings positive outcome in firm performance.

Second, the key finding of the relationship between entrepreneurial-market orientations and entrepreneurial-technology orientations indicates that entrepreneurial orientation is an antecedent of market and technology orientations. This result implies that entrepreneurial orientation can be seen as a key strategic behavior that is part of a system of strategic orientations that guides how the firm develops and deploys its 
resources for innovation. In other words, this finding affirms the notion that entrepreneurial orientation provides managers with the innovativeness, pro-activeness and risk-taking frame of mind required to embark on market orientation and technology orientation. This is similar with results of prior researches (Hult et al., 2004; Keskin, 2006; Rhee, Park, \& Lee, 2010).

Third, the findings show that both market and technology orientations are important drivers of firm performance. It was found that technology and market orientations positively affect firm performance. This result implies that technology and market orientations are key factors that influence firm performance in SMEs. This result is identical with results from antecedent researches (Augusto \& Coclho, 2009; Gatignon \& Xuereb, 1997; Hult et al., 2004; Rhee et al., 2010) which argue that technology and market orientations are closely related to firm performance. Our study also contributes an important explanation regarding the existence of a link between market orientation-firm performance and technology orientation-firm performance.

In conclusion, while market orientation and technology orientation may help managers to devise superior products, processes and ideas, entrepreneurial orientation provides the stimulus for driving such activities. This is because entrepreneurial orientation embodies the qualities of innovativeness, proactiveness and risk-taking. Accordingly, entrepreneurial orientation might be regarded as the spark the relationship between market orientation and technology orientation.

This research implies that an organization may need to strengthen entrepreneurial, market, and technology orientations to achieve improved firm performance. To achieve and maintain positive firm performance, a firm must possess an organizational structure that integrates and incorporates entrepreneurial, market and technology orientations into a coordinated framework that supports innovative activities to take advantage of the benefits that entrepreneurial, market, and technology orientations can allow.

The present study contributes to the literature on strategic orientation in a number of ways.

First, we particularly provided insight into how emerging country SMEs build strategic orientation for better firm performance. This overcomes the weakness in previous studies that have used a narrower focus of one or two dimension of strategic orientation. Thus, the present study helps the manager to better understand what types of strategic orientation should be encouraged with a view to increasing the level of firm performance.

Second, this research targets emerging country SMEs. Although many studies regarding strategic orientation have been done so far, a little research (Rhee et al., 2010) has been conducted in the SMEs context of emerging countries. A majority of previous research targets large companies (Hult et al., 2004) in developed countries rather than emerging country SMEs. However, this study extends previous literatures of strategic orientation to emerging country SMEs and shows the relevance of their theories and empirical findings.

The present study has a number of limitations and suggestions for further research.

First, the generalization of our results is limited. This research was conducted on Korean technology intensive SMEs. Future research could address these issues and explore new research questions, such as: comparing our model of strategic orientations and firm performance across two or more emerging countries, and also manufacturing and services business.

Second, this research did not analyze sub-construct variables of market orientation (competitor orientation, inter-functional coordination and customer orientation) and entrepreneurial orientation (innovativeness, pro-activeness, risk-taking). Future research could investigate sub-construct variables of market and entrepreneurial orientations for better understanding of the role of strategic orientation.

\section{References}

Akgun, A. E., Keskin, H., Byrne, J. C., \& Aren, S. (2007). Emotional and learning capability and their impact on product innovativeness and firm performance. Technovation, 27, 501-513. http://dx.doi.org/10.1016/j. technovation.2007.03.001

Aloulou, W., \& Fayolle, A. (2005). A Conceptual Approach of Entrepreneurial Orientation within Small Business Context. Journal of Enterprising Culture, 13, 24-45. http://dx.doi.org/10.1142/S021849580 5000045

Atuahene-Gima, K., \& Ko, A. (2001). An Empirical Investigation of the Effect of Market Orientation and Entrepreneurship Orientation Alignment on Product Innovation. Organization Science, 12, 54-74. http://dx.doi.org/10.1287/orsc.12.1.54.10121

Augusto, M. A., \& Coelho, F. (2009). Market orientation new-to-the-world product: Exploring the moderating effects of innovativeness, competitive strength, and environmental forces. Industrial Marketing 
Management, 38(1), 94-108. http://dx.doi.org/10.1016/j.indmarman.2007.09.007

Bagozzi, R., \& Yi, Y. (1988). On the evaluation of structural equation models. Journal of the Academy of Marketing Science, 16(1), 74-94. http://dx.doi.org/10.1007/BF02723327

Baker, W. E., \& Sinkula, J. M. (2009). The complementary effects of market orientation and entrepreneurial orientation on profitability in small businesses. Journal of Small Business Management, 47, 443-464. http://dx.doi.org/10.1111/j.1540-627X.2009.00278.x

Barringer, B. R., \& Bluedorn, A. C. (1999). The Relationship between Corporate Entrepreneurship and Strategic Management. Strategic Management Journal, 20, 421-444. http://dx.doi.org/10.1002/(SICI)1097-0266 (199905)20:5 <421::AID-SMJ30>3.0.CO;2-O

Becherer, R. C., \& Maurer, J. G. (1997). The Moderating Effect of Environmental Variables on the Entrepreneurial and Marketing Orientation of Entrepreneur-led Firms. Entrepreneurship Theory \& Practice, 22, 47-58.

Bhuian, S. N., Menguc, B., \& Bell, S. J. (2005). Just entrepreneurial enough: The moderating effect of entrepreneurship on the relationship between market orientation and performance. Journal of Business Research, 58, 9-17. http://dx.doi.org/10.1016/S0148-2963(03)00074-2

Brown, S. P., \& Peterson, R. A. (1994). Effect of effort on sales performance and job satisfaction. Journal of Marketing, 58, 70-80. http://dx.doi.org/10.2307/1252270

Browne, M. W., \& Cudeck, R. (1992). Alternative ways of assessing model fit. Sociological Methods and Research, 21, 230-258. http://dx.doi.org/10.1177/0049124192021002005

Covin, J. G., \& Slevin, D. P. (1989). Strategic management of small firms in hostile and benign environments. Strategic Management Journal, 10, 75-87. http://dx.doi.org/10.1002/smj.4250100107

Covin, J. G., \& Slevin, D. P. (1990). New venture strategic posture, structure, and performance an industry life-cycle analysis. Journal of Business Venturing, 5, 123-135. http://dx.doi.org/10.1016/0883-9026(90) 90004-D

Deshpandé, R., Farley, J. U., \& Webster, F. E. (1993). Corporate Culture, Customer orientation and innovativeness in Japanese Firms: A Quadrad Analysis. Journal of Marketing, 57, 23-37. http://dx.doi.org/10.2307/1252055

Farrell, M. A., Oczkowski, E., \& Kharabsheh, R. (2008). Market orientation, learning orientation and organisational performance in international joint ventures. Asia Pacific Journal of Marketing and Logics, 20, 289-308. http://dx.doi.org/10.1108/13555850810890066

Frishammar, J., \& Hörte, S. A. (2007). The Role of Market Orientation and Entrepreneurial Orientation for New Product Development Performance in Manufacturing Firms. Technology Analysis \& Strategic Management, 19, 765-788. http://dx.doi.org/10.1080/09537320701711231

Gao, G. Y., Zheng, K. Z., \& Yim, C. K. (2007). On what should firms focus in transitional economies? A study of the contingent value of strategic orientations in China. International Journal of Research in Marketing, 24, 3-15. http://dx.doi.org/10.1016/j.jiresmar.2006.09.004

Gatignon, H., \& Xuereb, J. M. (1997). Strategic Orientation of the Firm and New Product Performance. Journal of Marketing Research, 34, 77-90. http://dx.doi.org/10.2307/3152066

Grinstein, A. (2008). The relationships between market orientation and alternative strategic orientations A meta-analysis. European Journal of Marketing, 42, 115-134. http://dx.doi.org/10.1108/03090560810840 934

Hair, J. E., Anderson, R. E., Tatham, R. L., \& Black, W. C. (2006). Multivariate Data Analysis (6th ed.). Upper Saddle River, NJ: Prentice Hall.

Hakala, H. (2010). Configuring Out Strategic Orientation (p. 232). Universitas Wasaensis: Vaasan Liopisto.

Hakala, H. (2011). Strategic Orientations in Management Literature: Three Approaches to Understanding the Interaction between Market, Technology, Entrepreneurial and Learning Orientations. International Journal of Management Reviews, 13, 199-217. http://dx.doi.org/10.1111/j.1468-2370.2010.00292.x

Hamel, S., \& Prahalad, C. K. (1994). Competing for the future. Harvard Business Review, 72, 122-128.

Han, J. K., Kim, N., \& Srivastava, R. K. (1998). Marketing Orientation and Organizational Performance: Is Innovation a Missing Link? Journal of Marketing, 62, 30-45. http://dx.doi.org/10.2307/1252285 
Hartline, M. D., \& Ferrell, O. C. (1996). The Management of Customer-Contact Service Employees: An Empirical Investigation. Journal of Marketing, 60, 52-70. http://dx.doi.org/10.2307/1251901

Haugland, S. A., Myrtveit, I., \& Nygaard, A. (2007). Market orientation and performance in the service industry: A data envelopment analysis. Journal of Business Research, 60, 1191-1197. http://dx.doi.org/10.1016/j. jbusres.2007.03.005

Hult, G. T. M., Hurley, R. F., \& Knight, G. A. (2004). Innovativeness: Its antecedents and impact on business performance. Industrial Marketing Management, 33, 429-438. http://dx.doi.org/10.1016/j.indmarman. 2003.08.015

Im, S., \& Workman, S. (2004). The Impact of Creativity on New Product Success. Journal of Marketing, 68, 114-132. http://dx.doi.org/10.1509/jmkg.68.2.114.27788

Jaworski, B. J., \& Kohli, A. K. (1993). Market orientation: Antecedents and consequences. Journal of Marketing, 57, 53-70. http://dx.doi.org/10.2307/1251854

Jeong, I., Pae, J. H., \& Zhou, D. (2006). Antecedents and consequences of the strategic orientations in new product development: The case of Chinese manufacturers. Industrial Marketing Management, 35, 348-358. http://dx.doi.org/10.1016/j.indmarman.2005.06.010

Kaya, N., \& Seyrek, I. H. (2005). Performance Impacts of Strategic Orientations: Evidence from Turkish Manufacturing Firms. Journal of American Academy of Business, 6, 68-71.

Keskin, H. (2006). Market orientation, Learning orientation, and Innovation Capabilities in SMEs: An extended model. European Journal of Innovative Management, 9(4), 336-417. http://dx.doi.org/10.1108/14601060 610707849

Kline, R. B. (2005). Principles and Practice of Structural Equation Modeling (2nd ed.). London: Guilford Press.

Kohli, A. K., Jaworski, B. J., \& Kumar, A. (1993). MARKOR: A measure of market orientation. Journal of Marketing Research, 30, 467-477. http://dx.doi.org/10.2307/3172691

Li, J. J. (2005). The formation of managerial networks of foreign firms in China: The effects of strategic orientations. Asian Pacific Journal of Management, 22, 423-443. http://dx.doi.org/10.1007/s10490-0054118-8

Li, Y., Liu, Y., \& Zhao, Y. (2006). The role of market and entrepreneurship orientation and internal control in the new product development activities of Chinese firms. Industrial Marketing Management, 35, 336-347. http://dx.doi.org/10.1016/j.indmarman.2005.05.016

Liu, S. S., Luo, X., \& Shi, Y. Z. (2002). Integrating customer orientation, corporate entrepreneurship, and learning orientation in organizations-in-transition: An empirical study. International Journal of Research in Marketing, 19, 367-382. http://dx.doi.org/10.1016/S0167-8116(02)00098-8

Lumpkin, G. T., \& Dess, G. G. (1996). Clarifying the entrepreneurial orientation construct and linking it to performance. Academy of Management Review, 21, 135-172.

Lumpkin, G. T., \& Dess, G. G. (2001). Linking two dimensions of entrepreneurial orientation to firm performance: The moderating role of environment and industry life cycle. Journal of Business Venturing, 16, 429-451. http://dx.doi.org/10.1016/S0883-9026(00)00048-3

Martin-Consuegra, D., Molina, A., \& Esteban, A. (2007). An integrated model of price, satisfaction and loyalty. Journal of Product \& Brand Management, 18, 459-468. http://dx.doi.org/10.1108/10610420710834913

Megicks, P., \& Warnaby, G. (2008). Market orientation and performance in small independent retailers in the UK. The International Review of Retail, Distribution and Consumer Research, 18, 105-119. http://dx.doi. org $/ 10.1080 / 09593960701778192$

Miller, D. (1983). The correlates of entrepreneurship in three types of firms. Management Science, 29, 770-790. http://dx.doi.org/10.1287/mnsc.29.7.770

Miller, D. (1987). The structural and environmental correlates of business strategy. Strategic Management Journal, 8, 55-76. http://dx.doi.org/10.1002/smj.4250080106

Miller, D., \& Friesen, P. H. (1982). Innovation in conservative and entrepreneurial firms: Two models of strategic momentum. Strategic Management Journal, 3, 1-25. http://dx.doi.org/10.1002/smj.4250030102

Murphy, G. B., Trailer, J. W., \& Hill, R. C. (1996). Measuring performance in entrepreneurship research. Journal of Business Research, 36(1), 15-23. http://dx.doi.org/10.1016/0148-2963(95)00159-X 
Narver, J. C., \& Slater, S. F. (1990). The effect of a market orientation on business profitability. Journal of Marketing, 54, 20-35. http://dx.doi.org/10.2307/1251757

Nunnally, J. C. (1967). Psychometric Theory. New York: McGraw-Hill.

Oczkowski, E., \& Farrell, M. (1998). Discriminating between Measurement Scales using Non-Nested Tests and Two Stage Estimators: The Case of Market Orientation. International Journal of Research in Marketing, 15, 349-366. http://dx.doi.org/10.1016/S0167-8116(98)00007-X

Park, B. I., \& Ghauri, P. N. (2011). Key factors affecting acquisition of technological capabilities from foreign acquiring firms by small and medium sized local firms. Journal of World Business, 46, 116-125. http://dx. doi.org/10.1016/j.jwb.2010.05.023

Podsakoff, P. M., MacKenzie, S. B., Lee, J., \& Podsakoff, N. P. (2003). Common method biases in behavioral research: A critical review of the literature and recommended remedies. Journal of Applied Psychology, 88(5), 879-903. http://dx.doi.org/10.1037/0021-9010.88.5.879

Ramaseshan, B., Caruana, A., \& Pang, L. S. (2002). The effect of market orientation on new product performance: a study among Singaporean firms. Journal of Product \& Brand Management, 11, 399-409. http://dx.doi.org/10.1108/10610420210445514

Rhee, J., Park, T., \& Lee, D. H. (2010). Drivers of innovativeness and performance for innovative SMEs in South Korea: Mediation of learning orientation. Technovation, 30, 65-75. http://dx.doi.org/10.1016/j. technovation.2009.04.008

Slater, S. F., \& Narver, J. C. (1994a). Does competitive environment moderate the market orientation-performance relationship? Journal of Marketing, 58, 46. http://dx.doi.org/10.2307/1252250

Slater, S. F., \& Narver, J. C. (1995). Market orientation and the learning organization. Journal of Marketing, 59, 63-74. http://dx.doi.org/10.2307/1252120

Voss, G. B., \& Voss, Z. G. (2000). Strategic orientation and Firm performance in an artistic environment. Journal of Marketing, 64, 67-83. http://dx.doi.org/10.1509/jmkg.64.1.67.17993

Wiklund, J. (1999). The sustainability of the Entrepreneurial Orientation Performance relationship. Entrepreneurship Theory and Practice, 24, 37-48.

Wiklund, J., \& Shepherd, D. (2003). Knowledge-based resources, entrepreneurial orientation, and the performance of small and medium-sized businesses. Strategic Management Journal, 24, 1307-1314. http://dx.doi.org/10.1002/smj.360

Wiklund, J., \& Shepherd, D. (2005). Entrepreneurial orientation and small business performance: A configurational approach. Journal of Business Venturing, 20, 71-91. http://dx.doi.org/10.1016/j.jbusvent. 2004.01.001

Zahra, S. A., \& Covin, J. G. (1995). Contextual Influences on the Corporate Entrepreneurship-Performance Relationship: A Longtitudinal Study. Journal of Business Venturing, 10, 43-58. http://dx.doi.org/10.1016 /0883-9026(94)00004-E

Zehir, C., \& Eren, M. S. (2007). Field research on impacts of some organizational factors on corporate entrepreneurship and business performance in the Turkish automotive industry. Journal of American Academy of Business Cambridge, 10, 170-176.

Zhou, K. Z., \& Li, C. B. (2010). How strategic orientations influence the building of dynamic capability in emerging economies. Journal of Business Research, 63, 224-231. http://dx.doi.org/10.1016/j.jbusres.2009. 03.003

Zhou, K. Z., Yim, C. K. B., \& Tse, D. K. (2005). The effects of strategic orientations on technology and market-based breakthrough innovations. Journal of Marketing, 69, 42-60. http://dx.doi.org/10.1509/jmkg. 69.2.42.60756

\section{Copyrights}

Copyright for this article is retained by the author(s), with first publication rights granted to the journal.

This is an open-access article distributed under the terms and conditions of the Creative Commons Attribution license (http://creativecommons.org/licenses/by/3.0/). 